\title{
Startup - Commercialization process in Iranian Science and Technology parks
}

Ayatollah Momayez

Assistant Professor, Faculty of Entrepreneurship, University of Tehran, Tehran, Iran. amomayez@ut.ac.ir

\section{Editor Científico: José Edson Lara}

Organização Comitê Científico

Double Blind Review pelo SEER/OJS

Recebido em 06.05.2019

Aprovado em 21.06.2019

\section{(c) (7) (5)}

Este trabalho foi licenciado com uma Licença Creative Commons - Atribuição - Não Comercial 3.0 Brasil 


\begin{abstract}
This study aims to identify improvement process to Commercialization process in startups in science and technology parks across Tehran. This study in terms of aim is of applied research method categorized as survey method, where descriptive correlation method has been used in this study. Statistical population consists of managers working at startups in science and technology parks across Tehran $(\mathrm{N}=279)$. The sample size using Cochran formula was estimated 128 individuals, where sampling was performed in random. The instrument used in this study includes a questionnaire that its validity was confirmed by Panel of Experts. Reliability of questionnaire was confirmed by calculating Cronbach's alpha coefficient. Eight process were identified in analysis of improvement process to Commercialization process, that include Focusing on Product features, strengthening the company's financial resources, marketing management, development of business services, facilitating laws, develop marketing process, training and product standardization, that all define $75.72 \%$ of variance on process.
\end{abstract}

Key words: Startups; Commercialization, Science and Technology Parks, Factor Analysis

\title{
Startup - Processo de comercialização em parques de Ciência e Tecnologia
}

\section{Iranianos}

\section{Resumo}

Este estudo tem como objetivo identificar o processo de melhoria para o processo de comercialização em startups em parques de ciência e tecnologia em todo Teerã. Este estudo, em termos de objetivo, é do método de pesquisa aplicada, categorizado como método de pesquisa, onde o método descritivo de correlação foi utilizado neste estudo. A população estatística consiste de gerentes trabalhando em startups em parques de ciência e tecnologia em Teerã $(\mathrm{N}=279)$. O tamanho da amostra usando a fórmula de Cochran foi estimado em 128 indivíduos, onde a amostragem foi realizada de forma aleatória. $\mathrm{O}$ instrumento utilizado neste estudo inclui um questionário cuja validade foi confirmada pelo Painel de Especialistas. A confiabilidade do questionário foi confirmada pelo cálculo do coeficiente alfa de Cronbach. Oito processos foram identificados na análise do processo de melhoria do processo de Comercialização, que inclui o foco em características do produto, fortalecimento dos recursos financeiros da empresa, gerenciamento de marketing, desenvolvimento de serviços de negócios, facilitação de leis, desenvolvimento de processos de marketing, treinamento e padronização de produtos. \% de variação no processo.

Palavras-chave: Startups; Comercialização, Parques Científicos e Tecnológicos, Análise Fatorial. 


\section{Startup - Proceso de comercialización en parques de Ciencia y Tecnología}

\section{Iraníes}

\section{Resumen}

Este estudio tiene como objetivo identificar el proceso de mejora para el proceso de comercialización en startups en parques de ciencia y tecnología en todo Teherán. Este estudio, en términos de objetivo, es del método de investigación aplicado, categorizado como método de investigación, donde el método descriptivo de correlación fue utilizado en este estudio. La población estadística consiste en gerentes trabajando en startups en parques de ciencia y tecnología en Teherán $(\mathrm{N}=279)$. El tamaño de la muestra usando la fórmula de Cochran fue estimado en 128 individuos, donde el muestreo fue realizado de forma aleatoria. El instrumento utilizado en este estudio incluye un cuestionario cuya validez fue confirmada por el Panel de Expertos. La confiabilidad del cuestionario fue confirmada por el cálculo del coeficiente alfa de Cronbach. En el análisis del proceso de mejora del proceso de Comercialización, que incluye el enfoque en características del producto, fortalecimiento de los recursos financieros de la empresa, gestión de marketing, desarrollo de servicios de negocios, facilitación de leyes, desarrollo de procesos de marketing, entrenamiento y estandarización de productos. \% de variación en el proceso.

Palabras clave: Startups; Comercialización, Parques Científicos y Tecnológicos, Análisis Factorial

\section{Introduction}

What found by human plays a major role in improving quality of life and developing welfare level throughout the community, as well as developing social and economic level, yet the if practically this does not come true, and not entered to the market, or not provided for client, then it will not be necessitated (Mudambi et al, 2009). Commercialization is an essential step for success at inventions in the research context using the effort by companies' research (Godarzi et al, 2011). Commercialization means converting new academic findings and research ideas to technologies, services and products that can be supplied to market with the least cost and high quality (Meigonpoori \& Kalantari, 2013). Indeed, Commercialization of research is mentioned as large efforts that is carried out in order to sell research products aiming at gaining interest and having the outcomes by the tie between research and education and economic-social aims (Shahverdi et al., 2009). Fakor (2006) has known Commercialization as a process that convert the knowledge created in universities and research institutions to the products that can be supplied to market or industrial processes. Zhao (2004) considered the 
Commercialization as a process in which developing new ideas or research data and converting them to commercial products and services and supplying them to market are reported. Reddy Metla (2007) knew the Commercialization as the process of knowledge $t$ conversion process to productions and services with applicable usage or precious use.

Ghazinoori (2005) believed that Commercialization in sake of innovation process means that modern knowledge and technology must be oriented to applicant industries and companies from the supplier institutions. Spilling (2004) has considered Commercialization as a process of knowledge conversion existing in university entities to several types of economic activities. The mechanism to improvement and success of Commercialization is regarded as a complicated process influenced of different factors including business, social, economic, legal, financial, economic, historical, academic and infrastructural factors (Radfar et al, 2009).

Although a variety of studies aiming at representing a model for Commercialization of innovations has been carried out, their results have been all criticized. Yolande Moreau (2006) deduced that a proposed model for Commercialization of innovations in startupscannot be practiced, and any company in accordance to the type of product, the relevancy with community's needs, size of company and technology level, must find a proper strategy for marketing and Commercialization. A successful Commercialization of modern achievement and technology requires sufficient demand, superiority of technology to meet needs and proper marketing in an organization to deliver product to market (Poorezat et al, 2010). Value creation for customers and manger is a key factor for success and survival of startups (Berg, 2005). Furthermore, startupsplay a vital role to define and model processes of production, research and development, academic and technical enrichment, education and human development, knowledge transfer and expansion of innovation in any country (Farjadi and Riahi, 2007). Companies' successful reaction in dynamic environment to their needs in supply of technological products to market relies on access to customers and finds solutions to supply products and services (Markman et al., 2008). Common characteristics among startupscan be reported as their relatively high growth, needing to financial supply due to time consuming in product development, focusing on specific markets that are found with so many applicants, tendency to clustering in specific regions, tendency to transfer technology inside the region and etc (Alahyari fard, Abasi, 2011). Moosaei (2008) believes that comprehensive literature for development and Commercialization of product in industries directly can be used for the successful Commercialization process on technology from research centers to market. Finally, nine elements can affect the marketing and Commercialization process, including Unique, 
precious and distinctive product, focusing on a part of market, having a specific definition for product, using multitask teams with leaders, using leverage characteristic, size of market and development of market and technological use of product, and finally quality of implementation. A successful Commercialization requires sufficient demand, superiority of technology to meet needs and proper marketing in an organization to deliver product to market (Albrecht,2010). Other key elements of Commercialization of product include value and characteristics of product, simplicity and lack of complication of product, brand name, economic force and focusing on market, customers and customer-orientation, attention to economic factors, competition and competitors, public opinions, public Accelerating laws, macro programs and regulations, expansion of knowledge based companies, move with the appropriate strategy before production, long term vision, scheduling to enter to market, proper resources adapted with company's needs and ability to attract capital, or be a member in a big investment center and cooperate in university and industry (Farjadi and Riahi, 2007).

Commercialization process of products in startupsis not a linear process, yet consists of several groups of activities that each group is a set of nonlinear activities. Five steps including recognition of technology, convincing, decision making, applying technology and confirming results from important steps in using products of startupshave been reported (Bandarian, 2009).

Commercialization of technology as a technological product enjoys specific characteristics that must be taken into account. By Attention to such problems, technology plays a deterministic role for small and medium size companies. Commercialization of research results is the most important and fundamental responsibility of startups (Sarmad Saeidi \& Mameghani, 2011). Indeed, philosophy of such companies lies on supply and sale of modern views and commercialization of them. The entrance gate known as preliminary commercialization and/or the stage of proposing idea is a critical point, because failure at this stage will cost highly. Ability of startups in sale of new products and services is influenced of two factors of orientation at market and having a look into customers' needs and understand them (Hosseini, Arasteh, 2012). To adopt Commercialization process, startupsmust take five leading factors into their account:

-relative superiority: this represents superiority of new technology to previous methods or products.

-Compatibility: this represents the extent to which Compatibility existed between new technology and acceptable values, previous experiences and customer's needs. 
-complexity: this indicates to extent to which new technology was complicated and found with problems in terms of using and understanding it.

-Possibility of trial use: this represents the extent to which competition seen in implementing new technology in small scale.

-Observe ability: this represents the extent to which the results from production and applying new technology were simple for users and decision makers(Moghimi et al, 2010).

Mohammadi (2009) believes that key factors of success in Commercialization of technology include adapting advantages of technology with needs of market, lack of competing technology, accelerating rules, direct impact on human's health, simplicity of use or process and cost and benefit. Companies use different methods and models in the process of Commercialization, where three main process can be defined given that in which stage the Commercialization categorized:

- Reactive Commercialization: after a research project fulfilled and access on results provided, Commercialization comes to realize, and generally it can be used for the technologies that is accounted as a secondary result during implementing massive research projects.

- Proactive Commercialization: it is conducted before any research project, and the research projects began followed by having trust on Proactive Commercialization. This method can be used for the products that are specified before development of technology nature.

- Concurrent Commercialization: before starting a research project on Concurrent Commercialization, considerations are taken into account step by step going through the research project (Spilling, 2004).

According to what discussed above, this study aims to Identify improvement process to Commercialization process in startups in science and technology parks across Tehran. In general, the factors affecting the Commercialization process in startupscan be categorized to external and internal factors, that external factors include companies, and internal factors include characteristics of product and knowledge-based companies, of which Promoting and inhibiting factors affect adopting Commercialization process like marketing management, education and standardization. Figure 1 indicates factors affecting Commercialization of products at knowledge-based companies. 


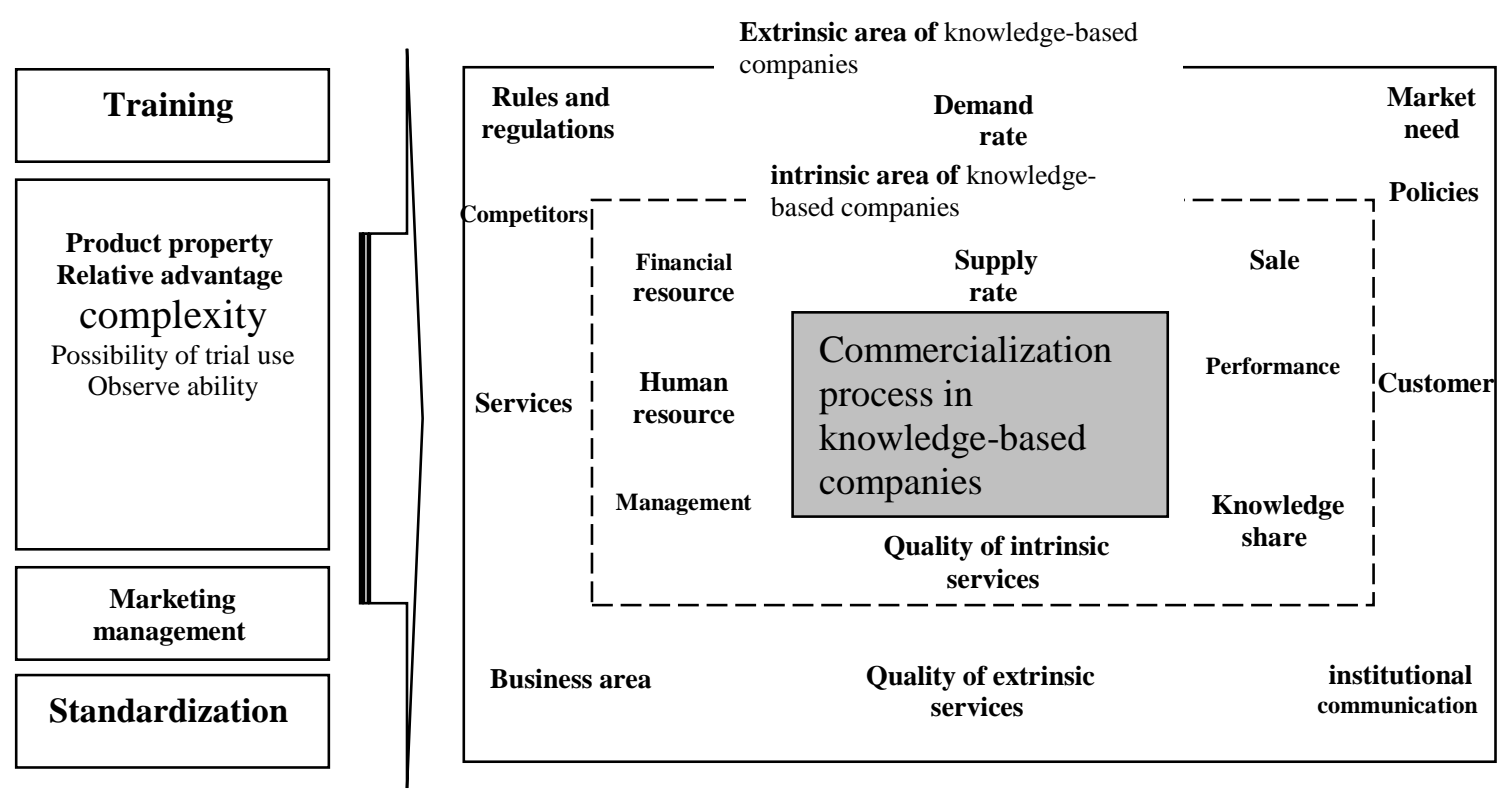

Figure 1:Factors affecting Materials and methods Commercialization of products at startups

This study aims to identify improvement process to Commercialization process in startups in science and technology parks. This study in terms of aim is of applied research method categorized as survey method, where descriptive correlation method has been used in this study. The research process was implemented in two library and field stages. Statistical population consists of managers working at startups in science and technology parks across Tehran $(\mathrm{N}=279)$. The sample size using Cochran formula was estimated 128 individuals, where sampling was performed in random. The instrument used in this study includes a questionnaire that its validity was confirmed by Panel of Experts. Reliability of questionnaire was confirmed by calculating Cronbach's alpha coefficient. The value for Cronbach's alpha mentioned equal to 0.87 . It should be noted that it can evaluate the appropriateness of improvement process to Commercialization process in startupswith respect to 40 questions in form of five-item Likert scale, i.e. very low, low, average, high and very high. Appropriate process were categorized and named using heuristic factor analysis.

\section{Research findings}

To identify improvement process to Commercialization process in startups in science and technology parks, heuristic factor analysis using the approach to determine significant variables 
in each of factors, was used. To fulfill factor analysis in this study, firstly an attempt is made to determine and identify the appropriateness of data for factor analysis using Kaiser-Meyer-Olkin coefficient and Bartellet Test. If the value of KMO be less than 0.50, data will not be appropriate for factor analysis, and if be in range of $0.50-0.70$, the correlations in data will be appropriate for factor analysis, and if be greater than 0.70 , the variables will be then appropriate. In the second stage, the number of factors must be specified. One of the important factors in factor analysis is determining the number of factors that can be extracted. Although, an accurate quantitative basis has not been proposed for decision making on the number of extractive factors, there are several regulations that they can be used in decision making to determine the number of extractive factors that include Eigenvalue criterion, Variance percentage, Cumulative percentage, cut testing standards, where Standard eigenvalue is used in this study. In analysis of improvement process to Commercialization process to identify appropriateness of data for analysis, KMO coefficient and Bartellet Test have been calculated, and the results indicated that data is appropriate for this analysis.

$$
(\mathrm{KMO}=0.727 \text {; Bartletts test }=3196.73, \mathrm{df}=820, \mathrm{sig}=0.00)
$$

Given appropriateness of data, the order for classification of data using analysis approach to main components was given, and the results shown in table 1 and 2 in below.

\section{Table 1}

Factors extracted together with Variance percentage, Cumulative percentage and Standard eigenvalue

\begin{tabular}{clccc}
\hline Row & Factors & $\begin{array}{c}\text { Standard } \\
\text { eigenvalue }\end{array}$ & $\begin{array}{c}\text { Variance } \\
\text { percentage }\end{array}$ & $\begin{array}{c}\text { Cumulative } \\
\text { percentage }\end{array}$ \\
\hline 1 & Focusing on Product features & 6.269 & 15.29 & 15.29 \\
2 & $\begin{array}{l}\text { strengthening the company's } \\
\text { financial resources }\end{array}$ & 5.628 & 13.72 & 29.01 \\
3 & marketing management & 5.342 & 13.03 & 42.04 \\
4 & development of business services & 5.258 & 12.82 & 54.87 \\
5 & facilitating laws & 3.538 & 8.74 & 63.61 \\
6 & develop marketing strategies & 1.786 & 4.35 & 67.96 \\
7 & training & 1.667 & 4.06 & 72.03 \\
8 & product standardization & 1.512 & 3.68 & 75.72 \\
\hline
\end{tabular}


Table 2

Variables on the factor and coefficient from the matrix

\begin{tabular}{|c|c|c|}
\hline Factor & Item & $\begin{array}{c}\text { Factor } \\
\text { coefficient }\end{array}$ \\
\hline \multirow{7}{*}{$\begin{array}{l}\text { Focusing } \\
\text { Product } \\
\text { features }\end{array}$} & distinctive product choice with market's demand & 0.617 \\
\hline & proper introduction into product & 0.706 \\
\hline & $\begin{array}{l}\text { easy use of product, and lack of complexity in terms of use and } \\
\text { understanding }\end{array}$ & 0.685 \\
\hline & proper functioning by product to meet customer's needs & 0.638 \\
\hline & compatibility of product with customer's values & 0.596 \\
\hline & attention to attractiveness of product in market & 0.583 \\
\hline & supply via brand & 0.695 \\
\hline \multirow[t]{5}{*}{$\begin{array}{l}\text { strengthening the } \\
\text { company's } \\
\text { financial resources }\end{array}$} & being provided with financial resources for commercialization & 0.503 \\
\hline & cost reduction for product commercialization & 0.544 \\
\hline & increasing legal and financial incentives for inventors and employees & 0.584 \\
\hline & management's ability & 0.595 \\
\hline & access to credits & 0.671 \\
\hline \multirow[t]{4}{*}{$\begin{array}{l}\text { marketing } \\
\text { management }\end{array}$} & emphasizing the market segment as targeted & 0.589 \\
\hline & accurate prediction and has a trust on sufficient market demand & 0.583 \\
\hline & identify potential customers & 0.654 \\
\hline & have access on marketing services and promotional products & 0.589 \\
\hline \multirow[t]{3}{*}{ facilitating laws } & Exemption from taxation & 0.657 \\
\hline & access to legal services & 0.539 \\
\hline & access to intellectual property & 0.749 \\
\hline \multirow[t]{2}{*}{$\begin{array}{l}\text { develop marketing } \\
\text { process }\end{array}$} & awareness of sale vision for products in global market & 0.694 \\
\hline & having a proper strategy fitted to aims of company & 0.685 \\
\hline training & training Commercialization methods to employees and managers & 0.537 \\
\hline $\begin{array}{l}\text { product } \\
\text { standardization }\end{array}$ & companies' access to standardization services for product & 0.527 \\
\hline
\end{tabular}


The obtained results indicate that eight factors explain about $75.72 \%$ of the variance on improvement process to Commercialization process in knowledge-based companies. The first factor named as Focusing on Product features as the most important strategy explain about $15.29 \%$ of variance on factors, and emphasis on distinctive product choice with market's demand, proper introduction into product, easy use of product, and lack of complexity in terms of use and understanding, proper functioning by product to meet customer's needs, compatibility of product with customer's values, attention to attractiveness of product in market and supply via brand, are reported by means of this factor.

The second strategy named as strengthening the company's financial resources has explained about $13.72 \%$ of variance on the factors, and focus on being provided with financial resources for commercialization, cost reduction for product commercialization, increasing legal and financial incentives for inventors and employees, and management's ability and access to credits.

The third strategy named as marketing management explains about $13.03 \%$ of the variance on process. This factor focuses on emphasizing the market segment as targeted, accurate prediction and has a trust on sufficient market demand, identify potential customers and have access on marketing services and promotional products.

The fourth strategy named as facilitating laws explains about $8.74 \%$ of the variance on improvement process. This strategy focuses on Exemption from taxation, access to legal services and access to intellectual property.

The fifth strategy named as development of business services explains about $12.82 \%$ of the variance on improvement process. This strategy focuses on facilitating laws and improving the communication between companies and research units.

The sixth strategy named as develop marketing process explains about $4.35 \%$ of the variance on improvement process. This factor focuses on awareness of sale vision for products in global market, and having a proper strategy fitted to aims of company. Startupshave not developed a proper marketing strategy for their own, so the company will be confused in a long term.

The seventh strategy named as training explains about $4.06 \%$ of the variance on improvement process. This factor focuses on training Commercialization methods to employees and managers.

The eighth strategy named as product standardization explains about $3.68 \%$ of the variance on improvement process. This factor focuses on companies' access to standardization services for product. 


\section{Conclusion}

Eight strategies were identified in analysis of improvement process to Commercialization process, that include Focusing on Product features, strengthening the company's financial resources, marketing management, development of business services, facilitating laws, develop marketing process, training and product standardization, that all define $75.72 \%$ of variance on process. Markmn and colleagues (2008) stated that successful act of these companies in a dynamic environment relies on their ability to provide innovative and technological products to market, access to customers and find solutions to provide services and products. Further, Reca believes that four factors including product, quality, price and content must be taken into account in management. The results of this study focus on this point and are recognized as the most important factor in Commercialization. The results of research by Alahyarifard and Abasi(2012), European union commission(1997), Kryhata (2007), Plva (2005), Shams and Afzal (1383), Wright and colleagues (2007) and Siegel (2003) know the financial resources as one of the factor which affect Commercialization, that this is totally in consistent with the results of this study. Given that parks are financially supported by government, and government has intervened in technology development policies, the policies are built based on market's needs.

Radfar et al(2009), Bandarian(2009), Moghimi et al(2009) has addressed marketing management as a component in improving Commercialization, that the results of this study were taken into account. The results of research by Kakborn showed that supportive rules can also affect Commercialization of knowledge. Further, the results of research by Poorezat et al(200) have called Bureaucracy and inflexibility of the system as a barrier and limitation in Commercialization, that this is totally relevant with the findings of this study.

\section{The suggestions as follows can be proposed}

-it is suggested evaluating the companies' financial funding mechanisms, for which it is preferred companies to be established as cooperative or stock companies.

-By establishing a department for some institutions like health institution, It is suggested providing an infrastructure to proliferate and facilitate Bureaucratic processes inside science and technology parks. 
-in Commercialization of product, considering product properties in terms of complexity, advantage and etc is of importance. Hence, it is suggested to have the products with the least complexity and price.

\section{References}

Balalian, A. A., Simonyan, H., Hekimian, K., Deckelbaum, R. J., \& Sargsyan, A. (2017). Prevalence and determinants of stunting in a conflict-ridden border region in Armenia-a cross-sectional study. BMC Nutrition, 3(1), 85.

Bandarian, R. (2009). Marketing and commercialization of new technologies, processes, critical success factors, Journal of Technology, No. 19, pp. 39.

Berg, Daniel(2005). Technology management: brand value and the technology sector, 14th International Conference on Management of Technology, 22-25 May 2005, Vienna, Austria).

Cokburn, A. and Highsmith, J.(2001). Agile software Development: The people factor", software management, 36(2), pp. 131-139. Available from: www.snip.gob.ni/xdc/Agile/AgileSoftwareDevelopme nt.pdf

Decter, M., Bennett, D. and Leseure, M. (2007).University to business technology transfer-UK and USA comparisons, Technovation, 27(3), pp. 145-155.

Fakoor, B. and Ansari, MT (2010). Evaluation methods and technology resources in small firms. Journal of Science and Technology Policy. Issue 2, Volume 4, pp. 105-93.

Farjadi, G., \& Riahi, P. (2007). Study of local market for Iranian science and technology parks. Quarterly Journal of Research and Planning in Higher Education, 13(2), 20-48.

Ghazinoori, S.R. (2005). Strategies \& trends for commercialization \& marketing of high technologies case study: Nanotechnology in Iran, 2nd Conference on Management of Technology, Tehran University, Iran.

Goudarzi, Mehdi; Bamdad sofi, Jahanyar; Arabi, Mohammad, Amiri, Maghsood (2012). Model for technology commercialization process in governmental research institutions. Journal Science and Technology Policy Research, Year IV, No. 2, pp. 41-56.

Hosseini, Jahed and Arasteh, H. (2013). External factors affecting the results of research in $\neg$ brand. Journal of Research and Planning in Higher Education program, No. 67, pp. 45-68. 
Kirihata, T. (2007). Critical Success Factors in the Commercialization Process of Intellectual Property by New Technology Based Firms in Japan”, the Kyoto Economic Review, 76(2), pp. 241-249.

Meygonpuri, M. Kalantari, Ismaili (2013). Strategy to identify factors influencing the commercialization of academic research in the field of nanotechnology in Iran. No. I, pp. 47-66.

Moghimi, M., et al (2010). Impact of environmental factors on the commercialization of ideas and research results. Strategic Management Studies, No. 2, pp. 113 -126.

Mohammadi, F (2009). Technology development and commercialization of research findings, barriers and solutions. Iran Polymer Engineering and Science Society, pp. 1-3.

Moosaei, A. (2008). A model designed to determine the opportunities and commercialization of their R \& D centers. Journal of parks, No. 14, pp. 13-21.

Moreau, Franck (2006), Strategy Development Process in Bernasconi, Michel; Harris, Simon; Moensted, Mette, High-tech Entrepreneurship; Managing innovation, variety and uncertainity, Routldge

Mudambi, S., Oliva, T. A., \& Thomas, E. F. (2009). Industrial marketing firms and knowledge transfer: Toward a basic typology of community structures. Industrial Marketing Management, 38(2), 181-190.

OECD (1997). Diffusing Technology to Industry: Government Policies and Programs, Paris, OECD/GD (97) 60. Available from: http://www.oecd.org.

Plewa, C. (2005). Differences in Perceived Benefits from University-Industry Relationships, ANZMAC 2005 Conference: Business Interaction, Relationships and Networks, University of Adelaide, South Australia.

Pourezzat A. and Heydari, E. (2011). Identification and classification of challenges and barriers in Commercialization using Q methodology. Journal - Science and Technology Policy Research, Year IV, pp. 49-62

Pourezzat, AA, Gholipour, Armin and Nadirkhanloo, Samira (2010). Explore barriers to entrepreneurship and the commercialization of university students in Tehran University. Journal of Science and Technology Policy. No. 4, pp. 75-65.

Radfar, R., Khamse, Abbas Madani, Hussam al (2009). Technology commercialization and economic factors in the development of technology. Journal of Technology, No. 20, pp. 33 40. 
Siegel, D.S., Waldman, D.A., Atwater, L.E. and Link, A.N. (2003). Commercial knowledge transfers from universities to firms: improving the effectiveness of university-industry collaboration”, Journal of High Technology Management Research, 14(1), pp. 111- 133.

Sarmad Saidi, Sohail and Mamghani AR (2012). New product development and product development productivity using marketing. Year Management Journal 22, No. 162, pp. 25 26.

Shahverdi, HR, Bahraini, Mohammadali, Yazdi, F. (2010). barriers in nano technology. Journal of Industrial Technology, No. 13, pp. 67-72.

Spilling, O.R. (2004). Commercialization of knowledge-conceptual framework, 13th Nordic Conference on Small Business (NCSB) Research, University of Adelaide, South Australia. Wright, M., Clarysse, B., Mustar P. and Lockett A. (2007). Academic Entrepreneurship in Europe, Edward Elgar, Cheltenham and Northampton; 172-3.

Zhao, F. (2004). Commercialization of research: a case study of Australian universities, Higher Education Research \& Development, 23(2), Pp. 223-236 